\title{
First record of extinct Paraconularia (Cnidaria, Scyphozoa) from Tethyan sequence (Upper Permian) of Spiti valley, Himachal Himalaya, India
}

\author{
Narendra K. Swami, Satish C. Tripathi, Ramesh Laishram, and Amit Dharwadkar
}

\begin{abstract}
An almost complete Tethyan marine sedimentary succession ranging in age from Precambrian to Cretaceous is exposed in Spiti valley in the Himachal Himalaya, India. The present study records and describes, for the first time, the occurrence of Paraconularia sp., belonging to the conulariids, from the Gungri Formation of Upper Permian age, in the Pin River (a tributary of the Spiti River) valley in the Himachal Pradesh. The specimen is quite well preserved, and its discovery from Tethyan sequence adds to the knowledge of the Permian conulariids from India.
\end{abstract}

Narendra K. Swami. Himalayan Geology Division, Geological Survey of India, Sector-E, Aliganj, Lucknow, 226024, Uttar Pradesh, India. narendraswami92@rediffmail.com

Satish C. Tripathi. Himalayan Geology Division, Geological Survey of India, Sector-E, Aliganj, Lucknow, 226024, Uttar Pradesh, India. sctgsilko@rediffmail.com

Ramesh Laishram. Geological Survey of India, Plot no. 3, Sector- 33B, Chandigarh, 160020, Chandigarh, India. rames.laishram@gmail.com

Amit Dharwadkar. Geological Survey of India, Sector-E, Aliganj, Lucknow, 226024, Uttar Pradesh, India.

amit.rama@gmail.com

Keywords: Upper Permian; Gungri Formation; Paraconularia; Spiti; PT boundary

Submission: 26 October 2016 Acceptance: 26 July 2017

\section{INTRODUCTION}

Geological record of the extinct group of conulariids (Cnidaria, Scyphozoa) ranges in age from Ediacaran to Triassic period (Feldmann and Babcock, 1986; Van Iten et al., 2006; Van Iten et al., 2008; Leme et al., 2008; Sendino and Darrell,
2009; Van Iten et al., 2016). A rare conulariid fossil specimen has been discovered for the first time from the lower part of the Siltstone Member of the Gungri Formation, about $500 \mathrm{~m}$ to the west of village Guling, on the left bank of the Pin River (a tributary of Spiti River), in Lahaul and Spiti district of Himachal Pradesh, India (Figure 1).

Swami, Narendra K., Tripathi, Satish C., Laishram, Ramesh, and Dharwadkar, Amit.. 2017. First record of extinct Paraconularia (Cnidaria, Scyphozoa) from Tethyan sequence (Upper Permian) of Spiti valley, Himachal Himalaya, India. Palaeontologia Electronica 20.3.42A: $1-6$

palaeo-electronica.org/content/2017/1964-paraconularia-tethyan-sequence

Copyright: September 2017 Palaeontology Association. This is an open access article distributed under the terms of Attribution-NonCommercial-ShareAlike 4.0 International (CC BY-NC-SA 4.0), which permits users to copy and redistribute the material in any medium or format, provided it is not used for commercial purposes and the original author and source are credited, with indications if any changes are made.

creativecommons.org/licenses/by-nc-sa/4.0/ 


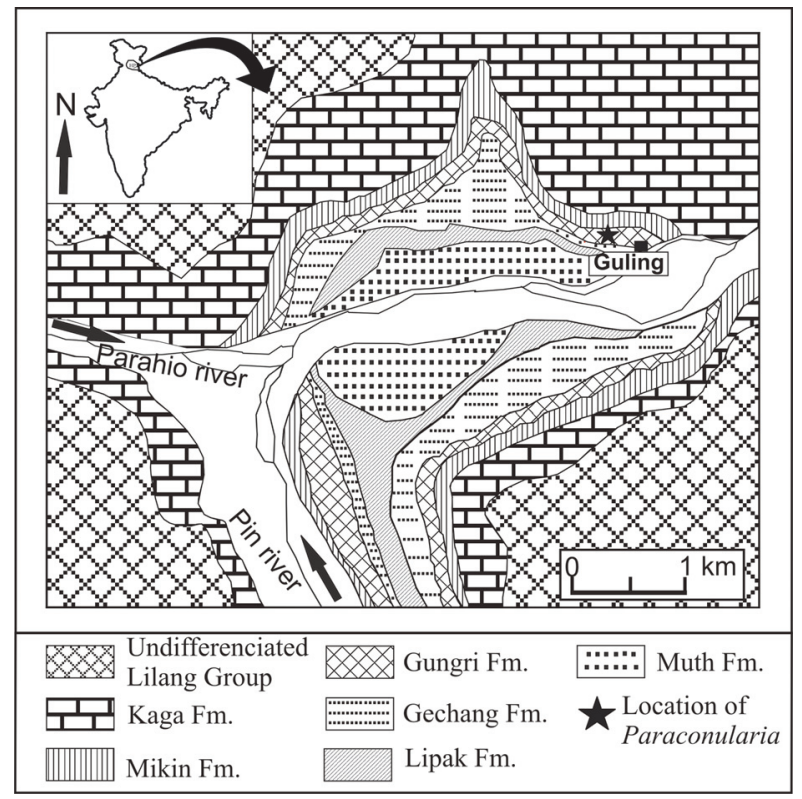

FIGURE 1. Geological map of the Pin River valley, Lahaul and Spiti district of Himachal Pradesh, India, showing location of the fossil specimen demarcated by star.

\section{GEOLOGICAL SETTING}

The Tethyan sequence of the Himachal Himalaya represents a more or less complete sedimentary succession ranging in age from the Precambrian to the Cretaceous. The Permian succession of Kuling Group of Spiti valley is subdivided into Gechang and Gungri formations in ascending order. The lower Gechang Formation consists of medium grained, grey to buff coloured argillaceous sandstone, which is often calcareous and contains recrystallised brachiopod shells. The Gungri Formation gradationally overlies the Gechang Formation and consists of a lower micaceous Siltstone Member and upper Nodular Black Shale Member (Figure 2).

The Siltstone Member of the Gungri Formation is richly fossiliferous and is characterized by brachiopods (Neospirifer and Linoproductus) and trace fossil Zoophycus (Figure 3.1). This member is succeeded upward by black shale containing phosphatic nodules (Figure 3.2). A continuous 1 to $6 \mathrm{~cm}$ thick, ferruginous layer representing PermianTriassic boundary is ubiquitous in this region (Figure 3.3). The Permian strata in the study area are overlain by the Triassic limestone sequence, represented by the Mikin Formation, which yields typical cephalopods (Octoceras and Ophioceras; Figure 3.4). The Gungri Formation has been assigned an age ranging from Dzulfian to Dorashmian of the

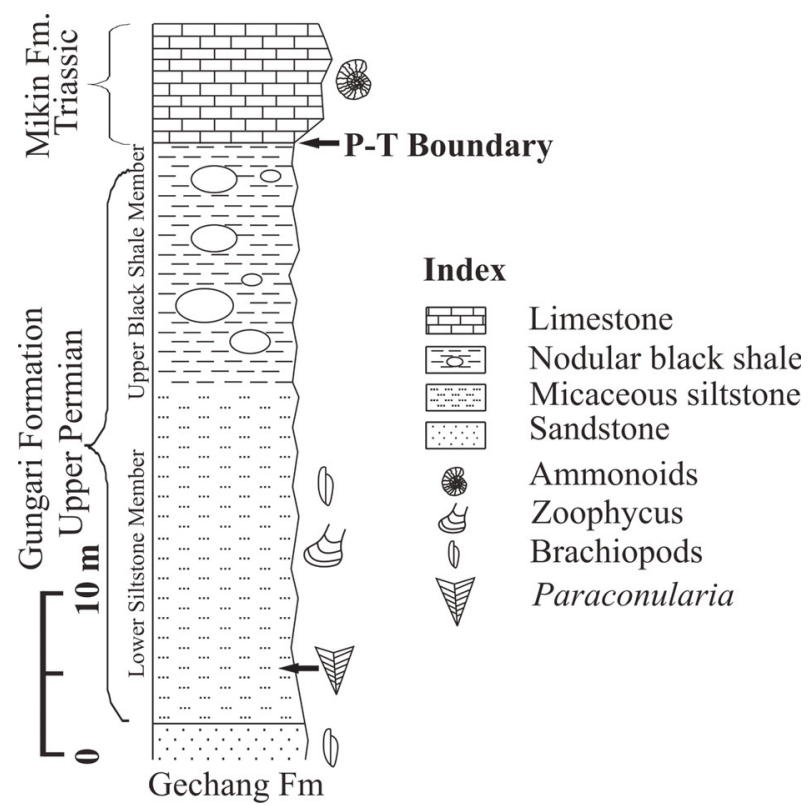

FIGURE 2. Litholog showing the stratigraphic level of the Paraconularia sp. with respect to Gungri Formation.

uppermost Permian on the basis of the faunal assemblages (Bhargava and Bassi, 1998; Bhargava, 2008).

\section{MATERIAL}

Single relatively quite well-preserved specimen. The original sample is in the Repository of the Geological Survey of India, Northern Region, Lucknow, India, registration number NRS-2/467.

\section{SYSTEMATIC PALAEONTOLOGY}

Phylum CNIDARIA Hatschek, 1888

Class SCYPHOZOA Gotte, 1887

Order CONULARRIDA Miller and Gurley, 1896

Family CONULARIIDAE Walcott, 1886

Genus PARACONULARIA Sinclair, 1940

Type species. Paraconularia inaequicostata de Koninck, 1883.

\section{Paraconularia sp.}

Figure 4

Horizon. Lower Siltstone Member of the Gungri Formation, Upper Permian.

Locality. About $500 \mathrm{~m}$ to the west of the village Guling, Lahaul and Spiti district, Himachal Pradesh, India.

Description. Relatively large (35mm long), incomplete specimen preserves the apical wall but does not preserve the apertural margin. The specimen shows unequal width of faces, has moderately high 

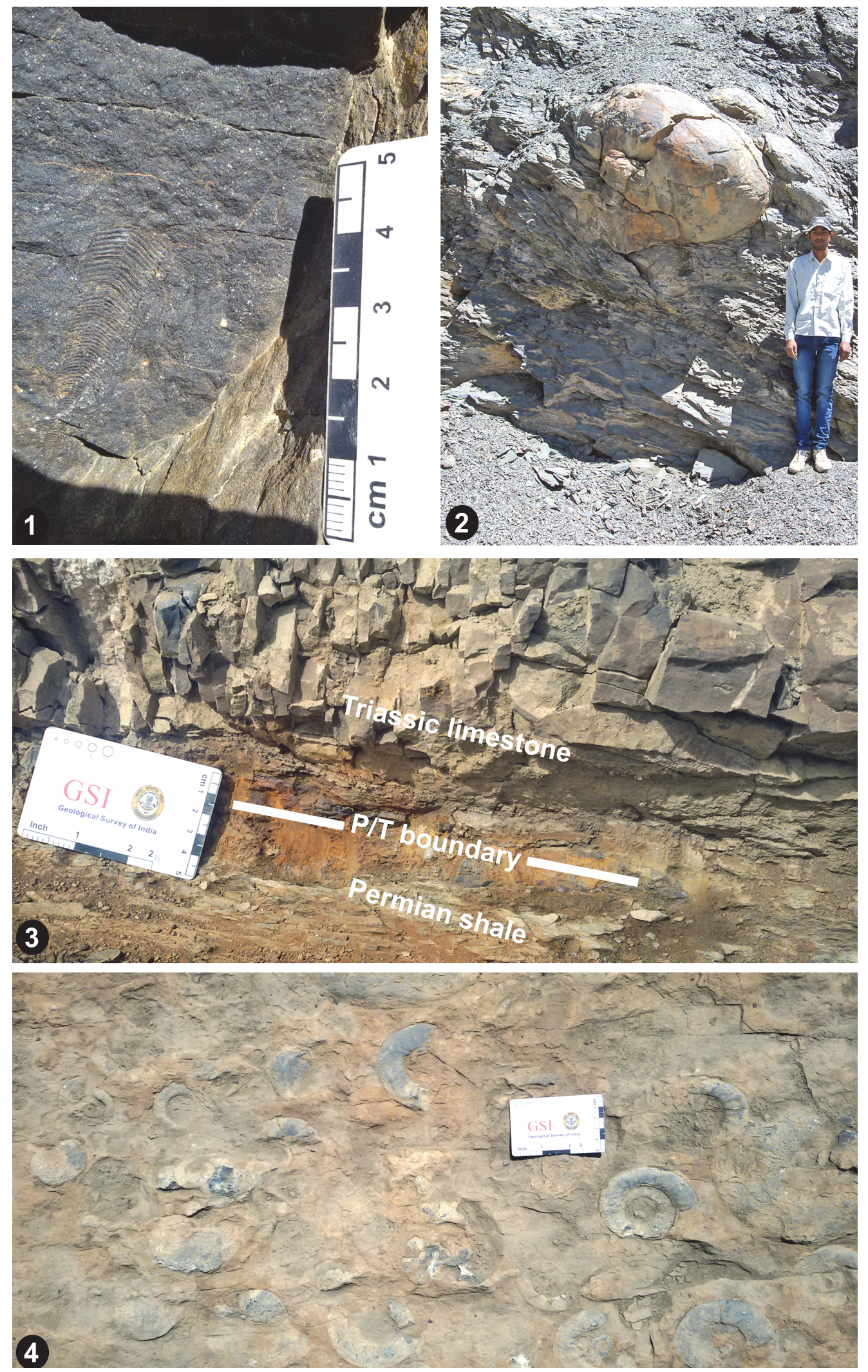

FIGURE 3. 1, Paraconularia embedded in the Micaceous siltstone of the lower part of Gungri Formation, Guling village. 2, Upper Nodular Black Shale Member of the Gungri Formation. 3, Permian-Triassic boundary, Guling village. 4, Ammonite bearing Triassic limestone of Mikin Formation, opposite to Guling village. 

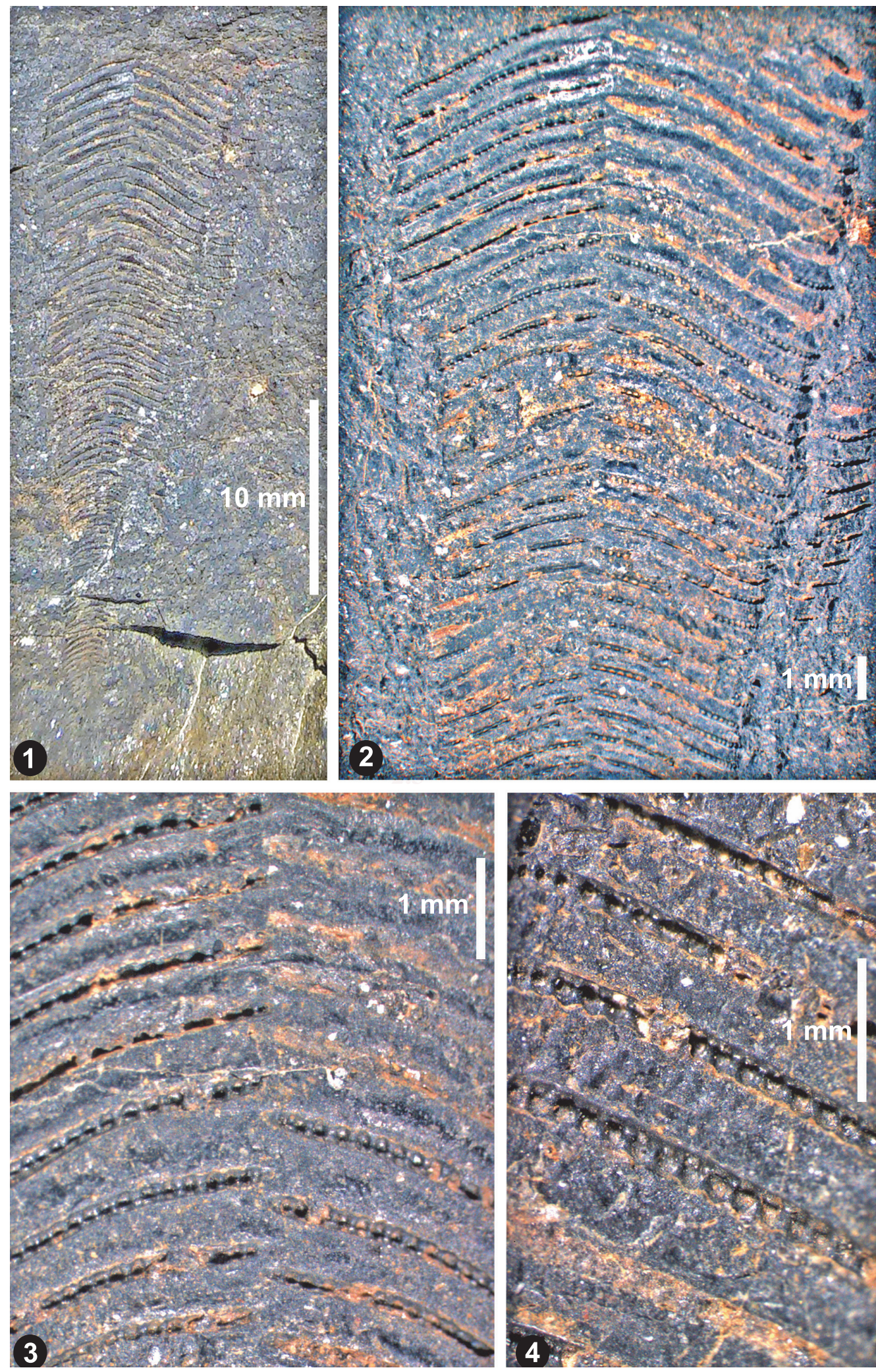

FIGURE 4. Paraconularia sp. embedded in the micaceous siltstone of the Gungri Formation. 1, View of single face. 2, Close-up view showing well-developed nodes on facial ridge (transverse rib) and interspace. 3, Apertural side showing widely spaced facial ridges, which alternately arranged either side of the midline. 4, Close-up view of the apertural side showing nodes on facial ridge. 
apical angle $\left(20^{\circ}\right)$ and is conical in shape. The facial ridges (transverse ribs) are around 52-55 in number, are moderately strong, thickening on the apertural side and thinning towards the apical side. The facial ridges occur at regular intervals, show slight curvature near the midline, exhibit chevronlike features but do not oppose each other. They are widely spaced (two ribs per millimeter) and terminate at the corner groove. Facial ridges are associated with well-preserved fine, closely spaced (six to seven nodes per millimeter), circular nodes on both sides (apical and apertural). The midline is faintly developed. Interspace (Interridge area) is smooth, slightly curved. Corner groove is partly preserved, and spines are completely absent.

Close resemblance. Based on the ornamentation and dimension of the present specimen, it closely resembles the Paraconularia quadrisulcata (Sowerby, 1821).

\section{DISCUSSION}

Fossils of conulariid have been reported earlier from Eastern Himalayas in the Lachi pebble bed of the Sagaramatha region (Acharyya and Shah, 1975); Conularia laskari from the Bighunala, Ranga valley in the Subansiri district of the Eastern Himalayas (Sahni and Srivastava, 1956); C. laevigata (Morris, 1845), C. warthi (Waagen, 1891), C. salaria (Reed, 1936), C. punjabica (Reed, 1936), and C. chelensis (Reed, 1936) from the Salt Range of Carboniferous/Early Permian age (Reed, 1936; Waterhouse, 1979). The Conularia bed of the Salt Range has been correlated with the Paraconularia of Badhaura Formation (Permian) of the Rajasthan and the fauna of Chumik Formation of the Kashmir (Waterhouse and Ranga Rao, 1989; Gaetani et al., 1990; Jain and Kumar, 2010).

While Paraconularia has been reported from the Lower Permian strata from other parts of the Himalaya, this study, for the first time, records its occurrence in the Gungri Formation of the Upper Permian age. Furthermore, faunas like brachiopods (Neospirifer and Linoproductus) and Zoophycus, which are associated with Paraconularia, suggest the presence of open marine, deep water, warm, muddy and sandy substrate condition.

\section{ACKNOWLEDGEMENT}

The authors are thankful to the Additional Director General and HoD, Geological Survey of India, Northern Region, Lucknow for permission to publish this work. The authors are also immensely grateful to A.K. Ghosh (BSIP, Lucknow), S. Shome (GSI, Kolkata), C. Sendino (Natural History Museum, London), N. Hughes (Department of Earth Sciences, University of California Riverside) and V. Singh (GSI, Lucknow) for help in the identification of fossil and review of the manuscript. Thanks are also due to an anonymous reviewer whose comments were greatly helpful in improving the manuscript.

\section{REFERENCES}

Acharyya, S.K. and Shah, S.C. 1975. Biostratigraphy of marine fauna associated with the diamictites of the Himalayas. Bulletin of the Indian Geological Association, 8:9-23.

Bhargava, O.N. 2008. An updated introduction to the Spiti geology. Journal of the Palaeontological Society of India, 53:113-129.

Bhargava, O.N. and Bassi, U.K. 1998. Geology of SpitiKinnaur Himachal Pradesh. Memoir of Geological Survey of India, 124:1-211.

de Koninck, L.G. 1883. Faune du calcaire carboniferede la Belgique, Pt. 4, Gastropodes. Annales Musee Royaled Histoire Naturelle de Belgique, Serie Paleontologie, 8:193-213.

Feldmann, R.M. and Babcock, L.E. 1986. Exceptionally preserved conulariids from Ohio-reinterpretation of their anatomy. National Geographic Research, 4:464-472.

Gaetani, M., Garzanti, E., and Tintori, A. 1990. PermoCarboniferous stratigraphy in SE Zanskar and NW Lahul (NW Himalaya, India). Eclogae Geologicae Helvatiae, 83:143-161.

Gotte, A. 1887. Entwicklungsgeschichte der Aurelia aurita und Cotylorhiza tuberculata. Abhandlungen zur Entwicklungsgeschichte der Tiere, Viertes Heft. Verlag von Leopold Voss, Hamburg and Leipzig.

Hatschek, B. 1888. Lehrbuch der Zoologie: Eine morphologische Ubersicht der Thierreiches zur Einfuhrung in das Stadium der Wissenschaft. Erste Liefrung. Fischer, Jena.

Jain, R.L. and Kumar, R. 2010. Palaeontological Study of Permian Fossils from the Bap and the Badhaura Formations Exposed in the Jodhpur and Bikaner Districts of Rajasthan. Unpublished Report, Geological Survey of India, Kolkata, India.

de Koninck, L.G. 1883. Faune du calcaire carboniferede la Belgique, Pt. 4, Gastropodes. Annales Musee Royaled Histoire Naturelle de Belgique, Serie Paleontologie, 8:193-213.

Leme, J.M., Simoes, M.G., Marques, A.C., and Van Iten, H. 2008. Cladistic analysis of the suborder Conulariina Miller and Gurley, 1896 (Cnidaria, Scyphozoa; Vendian-Triassic). Journal of Palaeontology, 51:649662.

Miller, S.A. and Gurley, W.F.E. 1896. New species of Palaeozoic invertebrates from Illinois and other 
states. Illinois State Museum of Natural History, Bulletin 11:1-50.

Morris, J. 1845. Descriptions of Fossils in Strzelecki, $P$. E. De, Physical Description of New South Wales and Van Diemen's Land. Longman, Brown, Green and Longmans, London.

Reed, C.F.R. 1936. Some fossils from the Eurydesma and Conularia beds (Punjabian) of the Salt Range. Memoir of Geological Survey of India, Palaeontologia Indica, 23:1-36.

Sahni, M.R. and Srivastava, J.P. 1956. Discovery of Eurydesma and Conularia in the Eastern Himalaya and description of associated faunas. Journal of the Palaeontological Society of India, 1:202-214.

Sendino, C. and Darrell, J. 2009. History of conulariid research. Journal of the Palaeontological Society of India, 54:121-133.

Sinclair, G.W. 1940. A discussion of the genus Metaconularia with descriptions of new species. Transactions of the Royal Society of Canada, 34:101-121

Sowerby, J. 1821. The Mineral Conchology of Great Britain; or Coloured Figures and Descriptions of Those Remains of Testaceous Animals or Shells, Which Have Been Preserved at Various Times and Depths in the Earth. W. Arding Company London.

Van Iten, H., Konate, M., and Moussa, Y. 2008. Conulariids of the Upper Talak Formation (Mississippian,
Visean) of Northern Niger (West Africa). Journal of Paleontology, 82:192-196.

Van Iten, H., Leme, J.M., Pacheco, M.L.A.F., Somoes, M.G., Fairchild, T.R., Rodrigues, F., Galante, D., Boggiani, P.C., and Marques, A.C. 2016. Origin and early diversification of Phylum Cnidaria: Key macrofossils from the Ediacaran System of North and South America, p. 31-40. In Gofferdo, S. and Dubinsky, Z. (eds.), The Cnidaria, Past, Present and Future. Springer International Publishing AG, Gewerbestrasse, Switzerland.

Van Iten, H., Leme, J.M., Simoes, M.G., Marques, A.C., and Collins, A.G. 2006. Reassessment of the phylogenetic position of conulariids (?Ediacaran-Triassic) within the subphylum Medusozoa (Phylum Cnidaria). Journal of Systematic Palaeontology, 4:109-118.

Waagen, W. 1891. Salt Range fossils. Palaeontologia Indica, 13:89-242.

Walcott, C.D. 1886. Cambrian faunas of North America. US Geological Survey, Bulletin, 30:72-89.

Waterhouse, J.B. 1979. Permian and Triassic conulariid species from New Zealand. Journal of the Royal Society of New Zealand, 9:475-489.

Waterhouse, J.B. and Ranga Rao, A. 1989. Early Permian brachiopods and molluscan species from the Bap Formation of Peninsula India. Palaeontologische Zeitschrift, 63:25-39. 